\title{
Increased fucosylation has a pivotal role in invasive and metastatic properties of head and neck cancer stem cells
}

\author{
Vincenzo Desiderio ${ }^{1,3, *}$, Petros Papagerakis ${ }^{4,5, *}$, Virginia Tirino ${ }^{3, *}$, Li Zheng ${ }^{2}$, \\ Margarite Matossian ${ }^{1}$, Mark E. Prince ${ }^{6}$, Francesca Paino ${ }^{3}$, Luigi Mele ${ }^{1,3}$, Federica \\ Papaccio ${ }^{3}$, Roberta Montella ${ }^{3}$, Gianpaolo Papaccio ${ }^{3, * *}$ and Silvana Papagerakis ${ }^{1,2, * *}$ \\ ${ }^{1}$ Department of Otolaryngology, Medical School, University of Michigan, Ann Arbor, MI, USA \\ 2 Department of Periodontics and Oral Medicine, School of Dentistry, University of Michigan, Ann Arbor, MI, USA \\ ${ }^{3}$ Department of Experimental Medicine, Section of Biotechnology and Medical Histology and Embryology, Second University \\ of Naples, Italy \\ ${ }^{4}$ Department of Orthodontics and Pediatric Dentistry, School of Dentistry, University of Michigan, Ann Arbor, MI, USA \\ ${ }^{5}$ Center for Organogenesis, Medical School, University of Michigan, Ann Arbor, MI, USA \\ ${ }^{6}$ Department of Otolaryngology, Head and Neck Surgery, Medical School, University of Michigan, Ann Arbor, MI, USA \\ ${ }^{7}$ Center for Computational Medicine and Bioinformatics, University of Michigan, Ann Arbor, MI, USA \\ * These authors contributed equally to this work \\ ** Equal senior Authors \\ Correspondence to: Gianpaolo Papaccio, email: gianpaolo.papaccio@unina2.it \\ Silvana Papagerakis, email: silvanap@umich.edu
}

Keywords: cancer stem cells, oral cancer, fucosylation, radiation, cisplatin

Received: July 22, $2014 \quad$ Accepted: November 06, $2014 \quad$ Published: November 06, 2014

This is an open-access article distributed under the terms of the Creative Commons Attribution License, which permits unrestricted use, distribution, and reproduction in any medium, provided the original author and source are credited.

ABSTRACT

Oral squamous cell carcinoma (OSCC) is an aggressive malignancy with high mortality rates. Major challenges for OSCC management include development of resistance to therapy and early formation of distant metastases. Cancer stem cells (CSCs) have emerged as important players in both pathologic mechanisms. Increased fucosylation activity and increased expression of fucosylated polysaccharides, such as Sialyl Lewis X $\left(\right.$ SLe $\left.^{x}\right)$, are associated with invasion and metastasis. However, the role of fucosylation in CSCs has not been elucidated yet. We used the spheroid culture technique to obtain a CSC-enriched population and compared orospheres with adherent cells. We found that orospheres expressed markers of CSCs and metastasis at higher levels, were more invasive and tumorigenic, and were more resistant to cisplatin/radiation than adherent counterparts. We found fucosyltransferases FUT3 and FUT6 highly up-regulated, increased SLe ${ }^{x}$ expression and increased adhesion by shear flow assays in orospheres. Inhibition of fucosylation negatively affected orospheres formation and invasion of oral CSCs. These results confirm that orospheres are enriched in CSCs and that fucosylation is of paramount importance for CSC invasion. In addition, SLe ${ }^{x}$ may play a key role in CSC metastasis. Thus, inhibition of fucosylation may be used to block CSCs and metastatic spread.

\section{INTRODUCTION}

Head and neck (H\&N) squamous cell carcinoma (HNSCC) is one of the world's top ten most common cancers: in fact, it is ranked the $8^{\text {th }}$ and $13^{\text {th }}$ most common malignancy, respectively, for males and females [1-3].
Unfortunately, current treatments for HNSCC can be traumatic and disfiguring, drastically affecting quality of life $[4,5]$. Management of HNSCC includes surgical resection and/or a combination of chemo- and radiotherapy $[1,6]$. Despite these treatments, the prognosis of HNSCC remains poor due to late diagnosis, high rates of 
primary-site recurrence, and common metastases to locoregional lymph nodes $[2,6,7]$.

Oral squamous cell carcinoma (OSCC), which includes epithelial neoplasms of the oral cavity and oropharynx, accounts for the majority of HNSCCs [8] and causes cancer-related mortality with an estimated $>275,000$ new cases and $>120,000$ deaths per year [9]. Despite the numerous advances in diagnosis and treatment of oral cancer, mortality and morbidity rates for OSCC are exceedingly high: the five-year survival rate of stage I cancer including the various sub-sites, such as borders of the tongue, floor of the mouth, cheek, and gums, is approximately $80 \%$, while the five-year survival rate of patients with advanced disease (stages III/IV) is approximately $20 \%$. Worldwide, about $50 \%$ of OSCC patients are diagnosed with advanced disease and the available treatment modalities are still limited. Therefore, novel treatment options and diagnostic tools are needed to improve disease outcome.

Cancer stem cells (CSCs) are a small subpopulation of self-sustaining cancer cells with the ability to form the heterogeneous cell lineages that compose the tumor [10]. CSCs are characterized by three main features: i) potent tumor initiation; ii) self-renewal in vivo (observed practically via re-growth of phenotypically indistinguishable tumors following serial transplantation of re-isolated CSCs in secondary and tertiary recipients); and iii) cell differentiation capacity, allowing them to give rise to a heterogeneous progeny representing a phenocopy of the original tumor [11]. CSCs have been proposed to be responsible for the aggressive behavior of several cancer types via the appropriation of the molecular machinery of homing and mobilization involved in tumor invasion and metastasis [12].

There are many methodologies to detect, isolate, and characterize CSCs from tumors: the main methods are cell sorting based on stemness marker expression, side population profiling, and formation of floating spheres [1315]. Sphere formation in vitro allows selection of CSCrich populations, and this method is particularly useful when specific CSC makers have not been well defined, as is the case for most cancer types [16]. CSCs have been identified in many solid tumors, including breast [17], lung [18], colon [19], prostate [20], ovary [21], brain cancer [22], and sarcoma [23]; in H\&N cancer, the existence of CSCs was first assessed using CD44 as a stem cell marker [24].

Fucosyltransferases (FUTs) are a family of Golgiapparatus enzymes that transfer L-fucose from GDPfucose to a glycoside or a peptide. According to the fucosylation site, FUTs are classified into alpha-1,2 (FUT1 and FUT2), alpha-1,3/4 (FUT3, FUT4, FUT5, FUT6, FUT7, and FUT9), and alpha-1,6 (FUT8) [25]. In mammals, fucosylated glycans are involved in cell adhesion during development [26, 27], the inflammatory response, and leukocyte trafficking [28, 29]. Great attention has been paid to FUTs and their inhibitors over the past 20 years due to the fact that addition of L-fucose is involved in a series of diseases, including cancer and metastatic spread [30-33]. Sialyl Lewis X $\left(\mathrm{SLe}^{\mathrm{x}}\right)$ is a cell-surface tetrasaccharide carbohydrate involved in many recognition processes. It is synthesized in the Golgi compartment by different glycosyltransferases, with the final step involving the transfer of L-fucose to $\mathrm{N}$-acetylglucosamine by alpha-1,3-FUT3/5/6/7, depending on the cell type [34].

In this study, we extensively compared orospheres with their adherent cell counterpart in terms of gene expression, stem cell and metastasis marker profile, cell adhesion and invasion, potential to form tumors in an animal model, and resistance to drugs and radiation. Moreover, we show that inhibition of fucosylation affects the orosphere formation and invasion ability of CSCs.

\section{RESULTS}

\section{Orospheres formation}

The ability to grow in suspension in serum-free medium was investigated with a tumor-initiating cellselection method. OSCC orospheres were clearly observed already after $24 \mathrm{~h}$ in serum-free medium. After 7 days of culture, orospheres were seeded onto standard plates with $10 \%$ FBS. Cells migrated from the spheres within a few hours and adhered to the bottom of the flasks, assuming their original shape.

\section{Orospheres have protein and RNA expression typical of CSCs and increased propensity to grow in vivo}

Orospheres and corresponding adherent cells of two OSCC lines (UMSCC14B and UMSCC103) were assessed for expression of CD44, CD29, CD56, sialyl Lewis $^{X}\left(\mathrm{SLe}^{\mathrm{X}}\right)$, sialyl Lewis A (SLa) and Lewis Y (Ly) as well as for aldehyde dehydrogenase (ALDH) activity. CD44 and ALDH activity are the most common markers of CSCs in OSCC $[24,35]$; CD29 is a $\beta 1$-integrin involved in invasion and metastasis that has been used as a CSC marker for different cancers [36]; and CD56 (N-CAM), which we describe here for the first time in oral cancer, has been correlated with invasion and distant metastasis in many cancers [37-39].

Cytometric analyses revealed that orospheres were remarkably more positive for ALDH activity than their adherent counterpart. In UMSCC14B cells, CD44 was more expressed on orospheres, while in the UMSCC103 cell line CD44 was more expressed by adherent cells. Nevertheless, in both cell lines, CD44-ALDH doublepositivity was remarkably higher in orospheres than 
corresponding adherent cells (Fig. 1A).

Similarly, CD29, CD56, and SLe ${ }^{\mathrm{x}}$ were consistently higher on orospheres than adherent cells (Fig1B). SLa was highly expressed by UMSCC14B but only slightly expressed by UMSCC 103 cell lines. No variations were observed between orospheres and adherent cells in both cases. Ly had a different pattern, being more expressed by orospheres in the UMSCC14B cell line, but more expressed by adherent cells in the UMSCC103 cell line. Neither SLa nor Ly seemed to be associated with the orospheres culture condition (Fig. 1B).

RNA from orospheres and adherent cells from both cell lines was extracted and PCR performed for genes related to stemness and metastasis. ALDH RNA expression was higher in orospheres of both cells lines, showing that orospheres not only have higher enzyme activity but that they also produce more ALDH. N-CAM RNA expression levels were also consistently higher in orospheres (Supplementary Table 1), as assessed by the cytometric analysis. Furthermore, the RNAs of VEGF,
A

A UMSCC14B

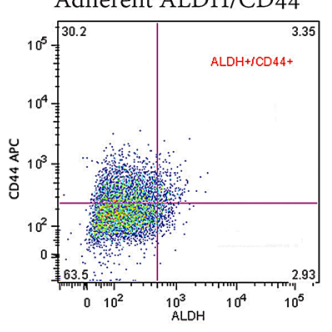

B

Summary of markers expression (mean positivity, Flow Cytometry)

\begin{tabular}{l|cc|cc} 
& $\begin{array}{l}\text { UMSCC14B } \\
\text { Adherent }\end{array}$ & Spheres & $\begin{array}{l}\text { UMSCC103 } \\
\text { Adherent }\end{array}$ & Spheres \\
CD29 & $77 \pm 8$ & $90 \pm 11^{*}$ & $90 \pm 9$ & $98,5 \pm 11$ \\
CD56 & $1,78 \pm 1$ & $29,7 \pm 4^{*}$ & $8,6 \pm 2$ & $12 \pm 3^{*}$ \\
Syalyl Lewis X & $37,2 \pm 5$ & $93 \pm 8^{*}$ & $93 \pm 4$ & $97 \pm 3^{5}$ \\
Syalyl Lewis A & $96 \pm 3$ & $96 \pm 4$ & $15 \pm 3$ & $21 \pm 5$ \\
Syalyl Lewis Y & $76 \pm 6$ & $34 \pm 5^{*}$ & $67 \pm 6$ & $89 \pm 7$ \\
CD44 & $33,5 \pm 4$ & $78 \pm 8^{*}$ & $80 \pm 6$ & $70 \pm 5$ \\
ALDH & $6,3 \pm 2$ & $15 \pm 3^{*}$ & $12,7 \pm 2$ & $18 \pm 3^{*}$ \\
ALDH+/CD44+ & $3,35 \pm 1$ & $11,9 \pm 2^{*}$ & $10,1 \pm 2$ & $10,3 \pm 3$ \\
\multicolumn{4}{|c}{ \$ mean fluorescence intensity $4.344 \pm 161$ vs $24.321 \pm 367^{*}$}
\end{tabular}

D

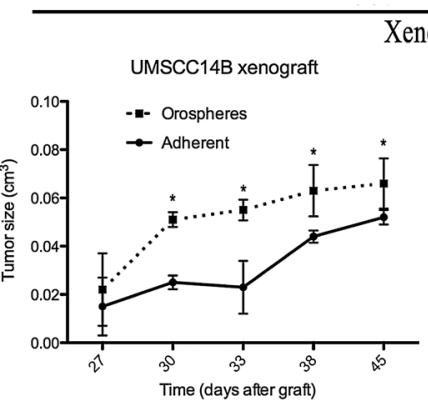

E

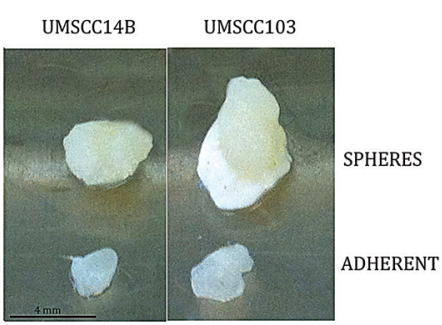

UMSCC14B

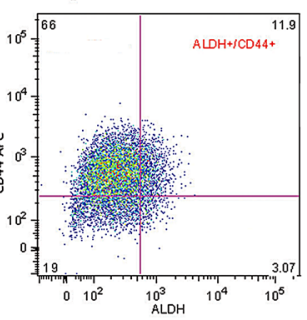

F

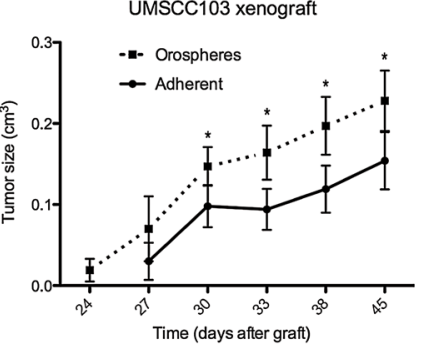

UMSCC103 Adherent ALDH/CD44

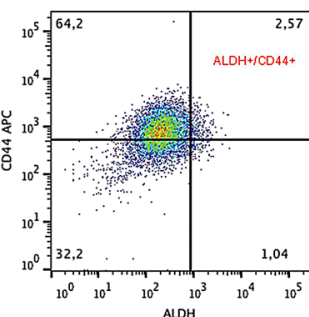

UMSCC103

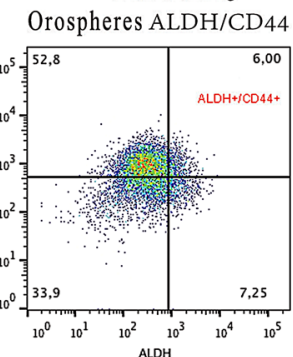

C

Real Time PCR
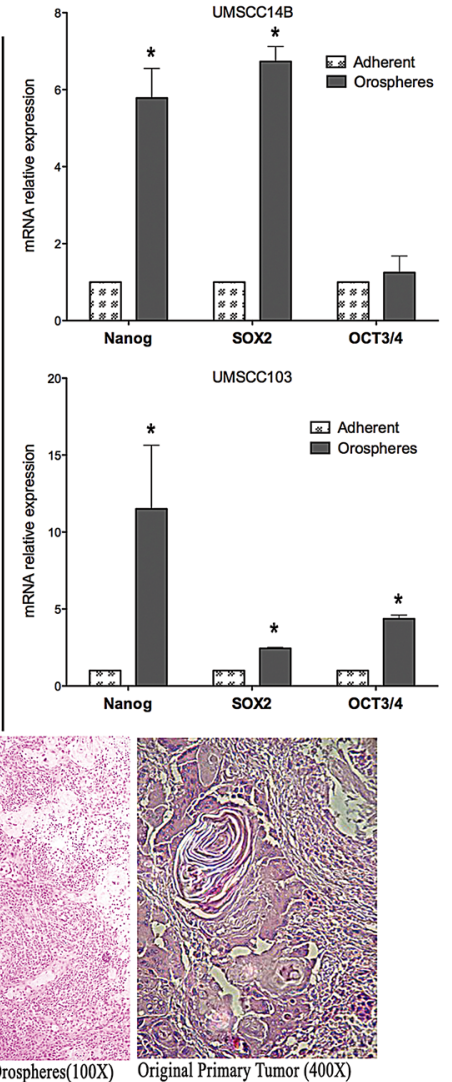

Figure 1: Cancer stem cell characterization. A. Flow cytometry analysis of CD44 and ALDH activity. The $\mathrm{CD}_{4}^{+} / \mathrm{ALDH}^{+}$ subpopulation is larger in orospheres in both UMSCC14B and UMSCC103 cell lines. B. Summary of marker expression in orospheres and adherent cells. ${ }^{*} \mathrm{P}<0.05 \mathrm{C}$. Real time PCR for the most common stem cell-related markers (OCT3/4, SOX-2, NANOG). All stem cell-related markers are remarkably more expressed on orospheres. ${ }^{*} \mathrm{P}<0.05$. D. Growth curve of orospheres and adherent cells implanted in immunocompromised mice. In both cell lines, the orospheres show faster growth, resulting in larger tumors at the time of sacrifice. E. Examples of explanted tumors for both cell lines. Orospheres produce remarkably larger tumors. Scale bar $=4 \mathrm{~mm}$. F. H\&E staining on sections of explanted and original primary tumors. Orospheres and adherent cells recapitulate the architecture of the original tumor. Original magnification: 100X (xenograft); 400X (original primary tumor). 
CXCR2, MMP10, PAR6, and FXYD5 (dysadherin), well-known markers associated with metastasis and poor prognosis in different cancers, including OSSC [40-43], were all up-regulated in orospheres (Supplementary Table 1 ), as were the RNAs of commonly recognized markers of normal stem cells and CSCs, such as SOX-2, OCT3/4, and NANOG (Fig. 1C).

To evaluate tumorigenic potential, orospheres and adherent cells were injected into the flanks of NOD/SCID immunodeficient mice. Tumor growth was measured every three days after tumors were first detected. 24-27 days after implantation, both orospheres and adherent cells were found to generate tumors in all cases, but although the same number of cells were injected, tumor size and growth of orospheres was significantly greater than that of adherent cells $(p<0.05)$ (Fig. 1D and 1E). Hematoxylin and eosin staining revealed that the xerographs reconstituted the characteristics of the original primary tumor architecture (Fig. 1F).

\section{Orospheres are resistant to Cisplatin and radiation treatment}

We performed a preliminarily dose-response evaluation of the growth inhibition induced by either cisplatin or radiation on adherent cell lines after $24 \mathrm{~h}$ of treatment (Supplementary Figure 1). On the basis of the results, we used for all the subsequent experiments the concentrations that caused at least $20 \%$ cell death. Therefore, the cell lines were treated with $80 \mu \mathrm{M}$ cisplatin and cell death analyzed after 24 hours. In both cell lines, orospheres had greater resistance to cisplatin-induced death than the corresponding adherent cells (Fig. 2A and Supplementary Table 2). In particular, the UMSCC103 cell line had higher sensitivity to cisplatin treatment, both as orospheres and adherent cells. In addition, IC50 was calculated from the dose-response curve assessed with a MTT assay (Fig.2B). For both cell lines, IC50 of orospheres was significantly higher than for adherent cells.

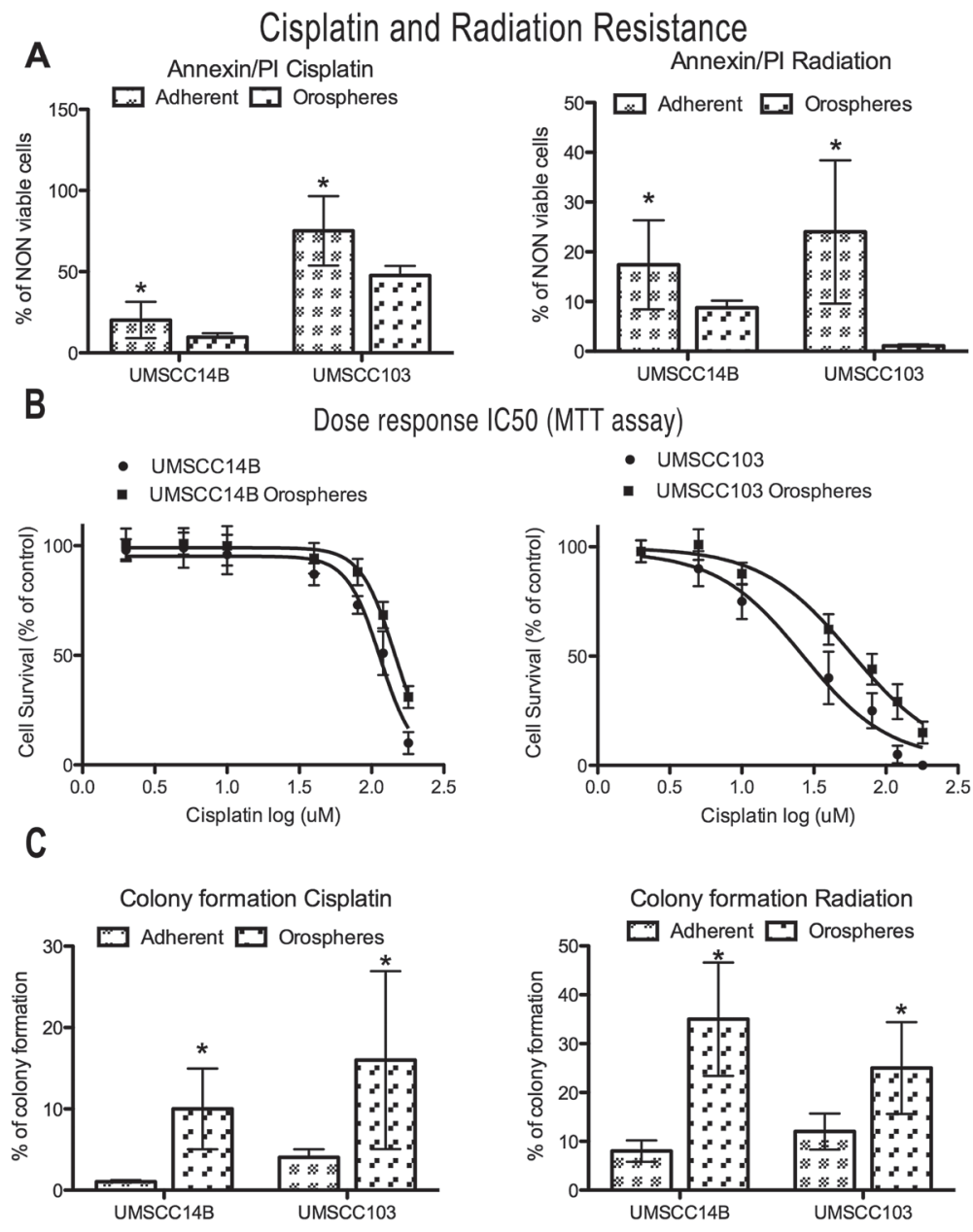

Figure 2: Cisplatin and radiation resistance. A. Graphs of non-viable (apoptotic+necrotic) cells measured by Annexin V/PI staining after cisplatin (after 24 hours) or radiation (after 48 hours) treatment. Orospheres are more resistant to both treatments. $* \mathrm{P}<0.05$. B. Doseresponse curves for IC50 calculation (UMSCC14B adherent cells, 114 (95\% CI 104-126); UMSCC14B orospheres, 144 (95\% CI 134-155); UMSCC103 adherent cells, 26.5 (95\% CI 18-39); UMSCC103 orospheres, 58 (95\% CI 47-72). C. Colony formation was measured 15 days after cisplatin or radiation treatment. Orospheres form significantly more colonies than adherent cells. $* \mathrm{P}<0.05$. 
IC50 values were: 114 (95\% CI 104-126) for UMSCC14B adherent cells, 144 (95\% CI 134-155) for UMSCC14B orospheres, 26.5 (95\% CI 18-39) for UMSCC103 adherent cells, and 58 (95\% CI 47-72) for UMSCC103 orospheres.

We also assessed radiation resistance. Even for this death stimulus, orospheres were more resistant than corresponding adherent cells (Fig. 2A). In both cell lines, a slight increase of necrosis was also found (Supplementary Fig. 2 and table 2). The findings were confirmed by colony forming assay (Fig. 2C and Supplementary Table 2): while adherent cells formed no or few colonies, orospheres were consistently able to form visible colonies.

\section{Orospheres are more invasive and show increased fucosylation}

The invasive ability of cells was then assessed with a Matrigel invasion chamber assay. Orospheres derived from the cell lines were significantly more invasive than

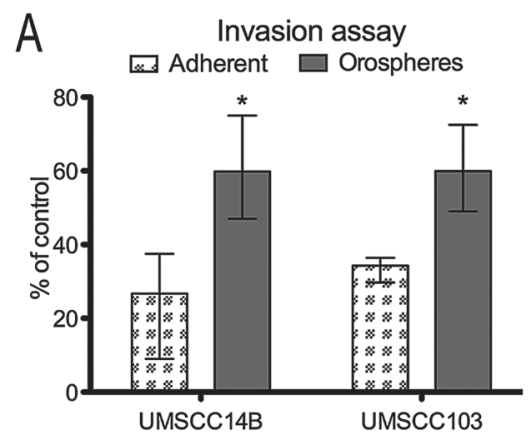

B

Quantitative PCR FUTS
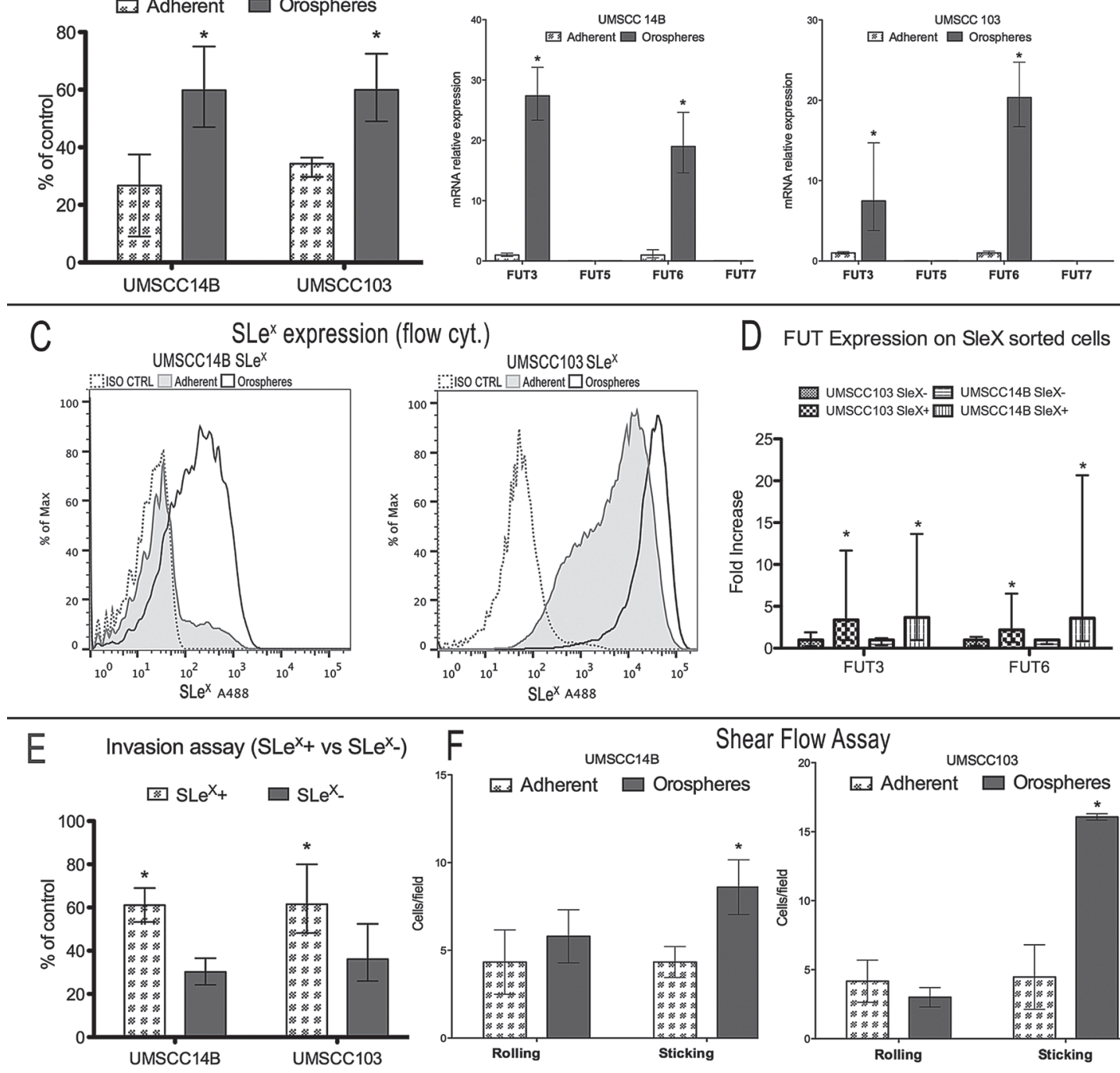

D FUT Expression on SleX sorted cells
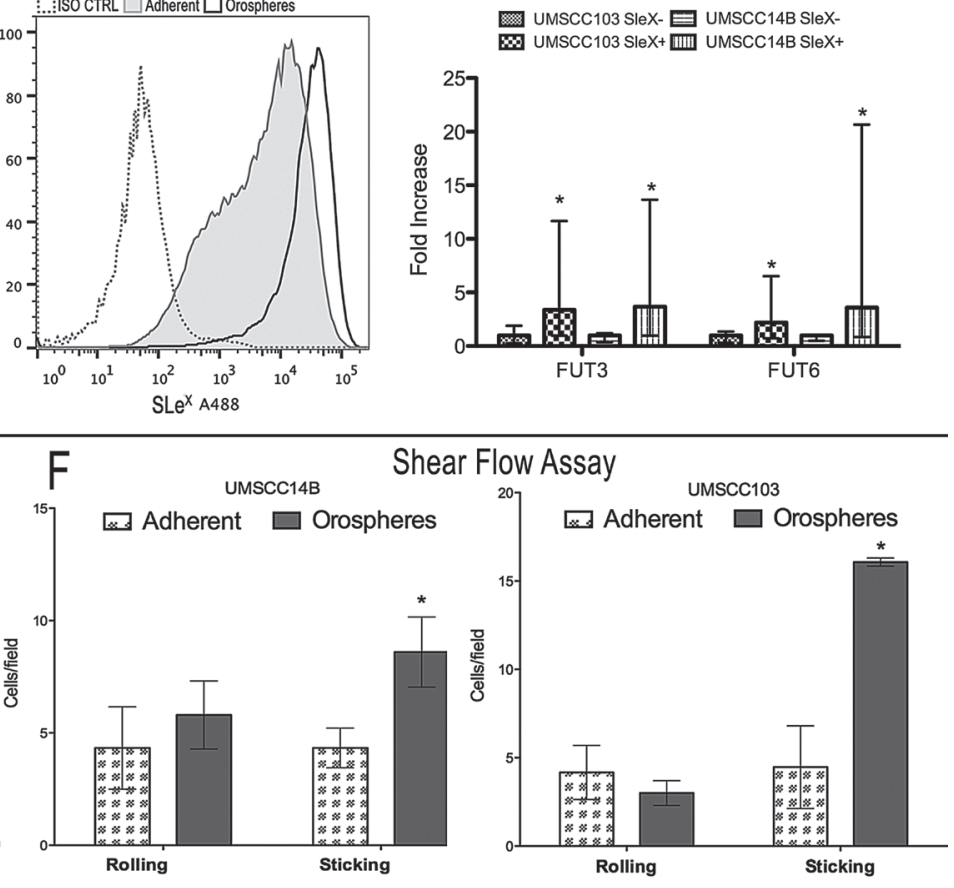

Figure 3: Fucosylation and SLe $\mathrm{S}^{\mathrm{x}}$ expression - functional assays. A. Invasion assay of orospheres vs adherent cells. Orospheres are significantly more invasive than adherent cells. B. Quantitative mRNA expression of FUTs. In both cell lines, FUT5 and FUT7 are not expressed, while FUT3 and FUT6 are more expressed in orospheres. C. Sialyl Lewis X (SLe ${ }^{\mathrm{x}}$ ) expression on orospheres and adherent cells (flow cytometry). Orospheres express a higher level of SLe ${ }^{\mathrm{x}}$ as compared with their adherent counterparts (UMSCC14B: 93\% for orospheres vs 27.2 for adherent cells; UMSCC103: 97\% for orospheres vs 93\% for adherent cells). Moreover, the mean fluorescence intensity for UMSCC103 is much higher than that of adherent cells, with most of the cells after the $4^{\text {th }}$ decade of fluorescence intensity. D. qPCR for FUT 3/6 expression on SLe ${ }^{x}$ sorted cells. SLe ${ }^{x+}$ cells have significantly increased FUTs expression. E. Invasion assay for SLe ${ }^{\mathrm{x}+}$ vs $\mathrm{SLe}^{\mathrm{x}-}$. SLe ${ }^{\mathrm{x}+}$ cells are significantly more invasive than $\mathrm{SLe}^{\mathrm{x}}$ cells. F. Shear flow assay. Graphs of percentages of firmly adherent (sticking) and rolling cells. The rate of firmly adherent (sticking) cells is higher for orospheres in both cell lines, while there is no significant difference in rolling cells. Moreover, the mean velocity of rolling cells is much lower for orosphere-derived cells than for adherent cells. $* P<0.05$. 
adherent cells: UMSCC14B orospheres-derived cells had a 2.4-fold increase, while those derived from UMSCC103 orospheres had a 1.75 -fold increased ability to migrate (Fig. 3A). Moreover, expression of FUT3 and FUT6 mRNA was significantly higher in orospheres (Fig. 3B), but FUT5 and FUT7 were not expressed in either adherent cells or orospheres (Fig. 3B). In addition, orospheres of both cell lines had a strong increase in the fucosylated carbohydrate $\mathrm{SLe}^{\mathrm{x}}$ (Fig 3C). In order to further investigate a possible relation between FUT and $\mathrm{SLe}^{\mathrm{x}}$ expression, we sorted cells for surface SLe ${ }^{\mathrm{x}}$, extracted the RNA, and performed qPCR for FUTs 3/6 expression. In both cell lines, the $\mathrm{SLe}^{\mathrm{x}+}$ subpopulation had a significantly higher expression of FUTs (Fig 3D). Consequently, we found that $\mathrm{SLe}^{\mathrm{x}+}$ cells had a significantly greater invasive ability than SLe ${ }^{\mathrm{x}-}$ cells. (Fig. 3E).

Shear flow is a functional analysis assessing the ability of cells to roll and stick on E-selectin-expressing endothelium. Rolling and adhesion to E-selectin -expressing endothelial cells is a key step for metastasis initiation. Orospheres-derived cells showed a significantly greater ability to adhere to E-selectin-expressing $\mathrm{CHO}$ cells than did adherent cells (Fig. 3F). In UMSCC14B and UMSCC103 cells, adhesion of orosphere-derived cells was respectively 2 -fold and 3.58-fold greater than their adherent counterpart. Rolling was not significantly different in the former; in the latter, orospheres rolled at slightly lower percentages than adherent cells, but the difference was not significant (Fig. 3F).

Of note, the maximum velocity calculated for UMSCC103 orospheres-derived cells $(31.83 \mu \mathrm{m} / \mathrm{s})$ was about half that of the adherent cells $(60.82 \mu \mathrm{m} / \mathrm{s})$, indicating that orospheres cells are more adherent to the monolayer. This correlation was found also for the UMSCC14B cell line.

\section{FUT inhibition reduces orospheres formation}

In order to evaluate the effect of fucosylation on orospheres formation, we incubated adherent cells with the specific inhibitor 2F-peracetyl-fucose for 72 hours prior to detaching the cells for orospheres formation. Inhibition of fucosylation with $2 \mathrm{~F}$-peracetyl-fucose resulted in the formation of fewer and smaller orospheres formation (Fig. 4A and B). Moreover, treatment significantly reduced invasion ability of orospheres (Fig. 4C): UMSCC14B cells had a 1.49-fold decrease, while UMSCC103 cells had a 1.7-fold decrease after treatment.

\section{DISCUSSION}

Prince el al. first described CSCs in H\&N cancer as a subpopulation of CD $44^{+} / \mathrm{CD} 24^{-/ \text {low }}$ cells [24]. Later, Clay et al. used ALDH1 activity to additionally characterize the stem-like subpopulation in H\&N cancers [35]. Recently, floating spheres have also been used to elucidate the roles of CSCs in H\&N cancer [44, 45].

To date, there is no available therapy targeting CSCs directly. A detailed characterization of CSCs and the discovery of new mechanisms involved in the metastatic process, stem-like feature acquisition, and drug resistance is necessary for the identification of more-effective strategies against this aggressive and resistant subset of cells. Increased fucosylation has been associated with metastatic and invasive properties of cancer cells [46-48]; moreover, inhibition of fucosylation has been successfully used against tumor growth and metastasis in vitro and in vivo $[49,50]$. In this light, our aim was to understand the role of fucosylation in CSCs-mediated invasion and metastasis in OSCC.

We firstly characterized H\&N-derived CSCs in terms of marker expression, tumorigenic potential, and metastatic and invasive ability. Both cell lines studied were able to grow as orospheres that could be passaged
A

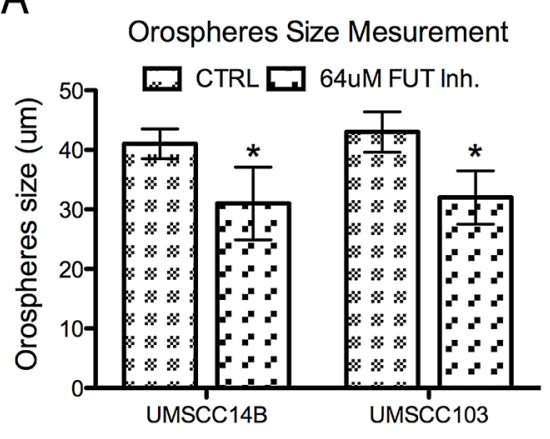

B

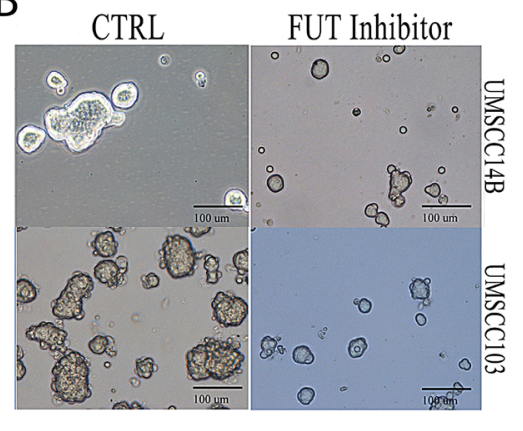

C

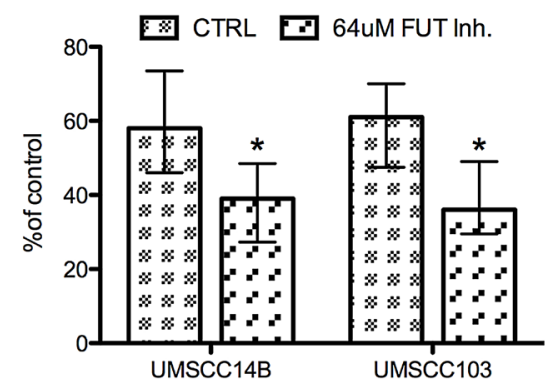

Figure 4: FUT inhibition. A. Orosphere size in cells treated with 2 F-peracetyl-fucose. Treated cells of both lines produced significantly smaller sized orospheres. B. Image of orospheres from $2 \mathrm{~F}$-peracetyl-fucose-treated and -untreated cells. C. Invasion assay of orospheres treated and untreated with 2F-peracetyl-fucose. Treated cells had significantly reduced invasion ability. 
for at least three times. Orospheres and adherent cells were analyzed comparatively for expression of several markers, including ALDH activity and CD44. It is generally accepted that ALDH activity and CD44 expression are reliable markers for CSC identification in carcinomas from the head and neck areas [24, 35, 51]. In our study, orospheres from both cell lines had increased ALDH activity compared with adherent counterparts. On the other hand, CD44 expression was higher in UMSCC14B orospheres than in adherent cells, differently to the UMSCC103 cell line, in which CD44 was more expressed on adherent cells. Nevertheless, the percentage of doublepositive cells for ALDH activity and CD44 expression was higher in orospheres than in adherent cells for UMSCC14B and UMSCC103 cell lines. Previous studies suggested that CD44 is also highly expressed in normal oral epithelium, similar to the expression detected in OSCC [52], while various CD44 variant isoforms that arise from alternative exon splicing are exclusively expressed in tumors, where they were significantly associated with advanced primary tumor stage, metastasis, treatment failure, and reduced disease-free survival $[53,54]$. For these reasons, CD44 should be used in combination with other markers for the reliable identification of CSCs.

Furthermore, orospheres had a pattern of gene expression typical of stem cells, characterized by upregulation of genes such as OCT4, NANOG, and SOX2. These findings were reinforced by up-regulation of other genes related not only to stemness but also to tumor progression and negative outcome, including NCAM and PAR-6 [42]. Interestingly, to our knowledge, CD56 (NCAM) has not been described before in OSCC-derived CSCs. NCAM is an homophilic binding glycoprotein expressed on the surface of various cells (e.g. neurons, glia, skeletal muscle, and natural killer cells), which has been correlated to invasion and distant metastasis in many human cancers, including small cell lung cancer, thyroid cancer, hepatocellular carcinomas, and glioma [37-39]. In order to better understand the potential links between CSCs and metastasis formation, we performed PCR arrays for genes related to metastasis. We found that orospheres overexpressed several genes, such as $V E G F$, FXYD5 (dysadherin), CXCR2, and MMP10, that have been strongly correlated with invasion and metastasis in many cancers, including $\mathrm{H} \& \mathrm{~N}$ carcinomas [40, 41, 43].

Two of the most important characteristics of CSCs are the ability to generate tumors in immunocompromised mice $[19,44]$ and resistance to conventional therapy [44, 55]. Here, we have demonstrated that tumors originating from orospheres grow faster and bigger than those originating from adherent cells, confirming the capacity of orospheres to initiate and sustain tumor growth. Moreover, cells derived from orospheres were significantly more resistant to cisplatin and radiation treatment than adherent cells. These results strongly suggest that orospheres are enriched in CSCs and that they represent a highly reproducible model for studying CSCs in OSCC.

Sialyl Lewis $\mathrm{X}$ is an E-selectin ligand with a carbohydrate structure that is constitutively expressed on granulocytes and monocytes, mediating inflammatory extravasation of these cells [56]. We found that SLe ${ }^{\mathrm{x}}$ expression was strongly associated with orospheres, confirming our recent preliminary report [57]. In different cancers, $\mathrm{SLe}^{\mathrm{x}}$ expression has been related to poor prognosis and metastasis, suggesting that it may be involved in cancer cell extravasation [58-61]. Consistently, we found increased expression of FUT3 and FUT6 (involved in $\mathrm{SLe}^{\mathrm{x}}$ synthesis) in orospheres concurrently to increased levels of SLe ${ }^{\mathrm{x}}$. In our model, other FUT3/6 products, such as SLa and Sly, were not associated with the orosphere culture condition. The expression pattern of these two Lewis family saccharides is discordant with the increase in FUT3/6 that we found in orospheres, suggesting that other enzymes may be responsible for their regulation. At the same time, sorted SLe ${ }^{\mathrm{x}+}$ adherent cells expressed significantly higher levels of FUT3/6 than did SLe ${ }^{\mathrm{x}-}$ cells. In addition a causal correlation between FUT3/6 and SLe $^{\mathrm{x}}$ levels has been showed in other models[34, 62-65]

Taken together, these findings strongly suggest that increased expression of FUT3/6 is associated with increased SLe ${ }^{\mathrm{x}}$ production. An invasion assay indicated that $\mathrm{SLe}^{\mathrm{x}+}$ cells (with high FUTs expression) levels were significantly more invasive than SLe ${ }^{\mathrm{x}-}$ cells (with low FUTs), suggestive of an association between FUTs expression and invasive phenotype.

Moreover, shear flow assays, mimicking the potential interaction between tumor cells and endothelium, showed that orospheres are remarkably more able to adhere to E-selectin-expressing cell layer, a feature that is of paramount importance for distant metastasis formation $[60,66]$. We did not find a significant difference in the number of rolling cells, but we did find a consistent and substantial difference in firmly adherent cell number and in the mean velocity of rolling cells. Thus, orospheresderived CSCs have greater ability to bind to E-selectin. $\mathrm{SLe}^{\mathrm{x}}$ is the main E-selectin ligand, and we found it to be overexpressed on orospheres-derived cells with increased FUT3/6 expression. 2F-peracetyl-fucose is the only commercially available inhibitor of fucosylation [67]. We show that inhibition of fucosylation negatively affects orospheres formation, producing smaller-sized spheroids. Sphere formation is widely used to enrich the CSC population, and is recognized as a standard tool to assess and confirm self-renewal in stem-like cells. Interestingly, inhibition of fucosylation also affected invasion ability of sphere-derived CSCs. Even though in vitro migration assays are not comprehensive methods for broad characterization of the invasive process, they have been extensively used and correlated to cancer invasion in vivo $[63,64]$. Moreover, inhibition of fucosylation affects E-selectin binding and cell extravasation [49], 
and Cheng et al. [68] showed that FUT family members, including FUT6, are involved in multidrug resistance in hepatocellular carcinomas. Based on this previous data and on the findings of this study, we hypothesize that increased fucosylation may be a mechanism used by CSCs to acquire not only invasive and metastatic features, but also resistance to conventional therapy.

\section{CONCLUSIONS}

Our study demonstrates the following: (i) orospheres are enriched in CSCs, express higher levels of metastatic markers, and are more tumorigenic than adherent counterparts; and (ii) fucosylation is of paramount importance in the invasion and metastatic process of CSCs. Among fucosylated saccharides, Sialyl Lewis X is a strong candidate in the acquisition of a FUT-associated invasive phenotype. Thus, inhibition of fucosylation may represent an active therapeutic tool against cancer stem cells and metastatic spreading.

\section{METHODS}

\section{Ethics Statement}

The investigation was conducted in accordance with the ethical standards and according to the Declaration of Helsinki and according to national and international guidelines and has been approved by the authors' institutional review board.

\section{Cell culture and orospheres formation}

OSCC cell lines (UMSCC14B, UMSCC103), used in this study were established at the University of Michigan under a protocol approved by the Institutional Review Board Office in accordance with the university's regulations [69, 70]. Cells were cultured in DMEM (Gibco, NY, USA) supplemented with $2 \mathrm{mM}$ glutamine, $100 \mathrm{IU} / \mathrm{ml}$ penicillin, $100 \mu \mathrm{g} / \mathrm{ml}$ streptomycin (Invitrogen, Carlsbad, CA), and 10\% heat-inactivated fetal bovine serum (FBS) (Invitrogen Life Technologies, NY, USA) at $37^{\circ} \mathrm{C}$ in a humidified atmosphere under $5 \% \mathrm{CO}_{2}$. Cells were passaged at a split ratio of 1:3-1:6. The cell lines used in this study were negative in periodic monitoring for mycoplasma. The cell lines were also genotyped to rule out cross-contamination and their morphology was regularly examined.

For orosphere formation, cells were plated at a density of $3 \times 10^{5}$ cells in $25 \mathrm{~cm}^{2}$ ultra-low-attachment flasks (Corning, NY, USA) in DMEM/F12 supplemented with B27 and N2 supplement (Gibco, NY, USA), 100 IU/ $\mathrm{ml}$ penicillin, and $100 \mu \mathrm{g} / \mathrm{ml}$ streptomycin (Invitrogen, Carlsbad, CA). Human fibroblast growth factor (FGF, 20ng/ml) and epidermal growth factor (EGF, 20ng/ ml) (both from Sigma Aldrich, MO, USA) were added every other day. After 48-72 hours, orospheres were enzymatically dissociated and re-cultured in the same condition to form second- and then third-passage orospheres, which were used for experiments. Inhibition of fucosylation was obtained as described by Rillahan et al. [67] using the fucosyltransferase inhibitor 2F-PeracetylFucose (Millipore Calbiochem, Merck KGaA, Darmstadt, Germany) at $64 \mu \mathrm{M}$ for 72 hours prior to performing experiments. To assess effect of $2 \mathrm{~F}$-Peracetyl-Fucose on orosphere formation, the number and size of orospheres were measured. At least 50 spheres for each sample were measured, reporting the diameter as mean with $95 \%$ confidence interval. 2F-Peracetyl-Fucose did not affect viability at the concentration used (Supplementary Figure 3).

\section{Phenotypic characterization and ALDH activity assay of orospheres vs adherent cells}

For flow cytometry, adherent cells were detached with trypsin/versene dissociation medium (Gibco, NY, USA). Briefly, the culture medium was discharged, cells were washed in PBS, and dissociation medium added and kept until cells detached from flasks. For dissociation of spheres, spheres were collected by centrifugation, washed with PBS (Gibco, NY, USA), and then $1 \mathrm{ml}$ of dissociation medium added until the orospheres were completely dissociated. Cells were re-suspended at $1 \times 10^{6} \%$ $\mathrm{ml}$ and incubated with primary antibody for 30 minutes on ice in the dark. Secondary antibodies, when needed, were added after a PBS wash for 30 minutes in the same conditions. Primary antibodies were PE-CD24, PE/Cy5CD29, FITC-CD56 (N-CAM), not conjugated CD15s (SleX, mouse IgM), and APC-CD44 (BD, CA, USA). SLa (sialyl Lewis A, mouse IgG) and Ly (Lewis Y, mouse IgM) were not conjugated (Abcam, Cambridge, UK). Alexa488conjugated secondary anti-mouse IgM and IgG antibodies were purchased from Life Technologies (NY, USA).

The Aldefluor kit (STEMCELL Technologies, BC, Canada) was used to identify cell populations with high aldehyde dehydrogenase (ALDH) activity. Briefly, $10^{6}$ harvested cells were resuspended in Aldefluor assay buffer containing ALDH substrate, as recommended by the producer. As a negative control for all samples, an aliquot of "Aldefluor-exposed" cells was immediately quenched with a specific ALDH inhibitor, diethylaminobenzaldehyde (DEAB). After incubation for $30 \mathrm{~min}$ at $4^{\circ} \mathrm{C}$ and following centrifugation, the cells were resuspended in cold Aldefluor buffer, and stained with 1 $\mu \mathrm{g} / \mathrm{ml}$ propidium iodide (PI) (Sigma Aldrich, MO, USA) to discriminate viable from dead cells. Aldefluor staining was detected in a green fluorescence channel. Samples treated with the inhibitor DEAB (+DEAB) were used as 
controls to set the gates defining the $\mathrm{ALDH}^{+}$region. Flow cytometry analyses and sorting were performed at the University of Michigan Flow Core using a FACS ARIA III (Becton Dickinson), a MoFlow Astrios (Beckman Coulter, Inc), a FACS Canto III (Becton Dickinson), or a MacsQuant (Miltenyi Biotec). All data were analyzed by Flow-Jo software (Tree Star, Inc).

\section{RNA isolation, qRT-PCR, and PCR arrays}

Total RNA was isolated by using TRIzol (Invitrogen, NY, USA). RNA (2 $\mu \mathrm{g})$ was reverse transcribed with TaqMan reverse transcription reagents (Applied Biosystems, Branchbury, NJ, USA), following the manufacturer's recommendations. The resulting cDNA was then amplified by real time RT-PCR (qRTPCR) using AmpliTaq Gold DNA Polymerase (Applied Biosystems). The RT-PCR products were subcloned into pGEM-T Easy vector (Promega, Madison, WI) and confirmed by sequencing. For RNA quantification, qRTPCR amplifications were performed at $95^{\circ} \mathrm{C}$ for $30 \mathrm{~s}$, $60^{\circ} \mathrm{C}$ for $30 \mathrm{~s}$, and $72^{\circ} \mathrm{C}$ for $30 \mathrm{~s}$ using specific primers for the house-keeping gene $\beta$-actin (Actb). The PCR primers sequences are given in Supplementary Table 1. The relative expression levels for each gene were calculated based on the expression levels of Actb and the differences are presented in graphs using the 2- $\Delta \Delta C \mathrm{CT}$ method. $\mathrm{P}$-values were calculated using two-sample t-test.

PCR arrays were purchased from Qiagen (QIAGEN, Valencia, CA). The arrays and data analyses were performed at University of Michigan's DNA core.

\section{Xenograft formation in NOD/SCID mice}

Adherent cells and orospheres were enzymatically dissociated to obtain single-cell suspensions, diluted to $5 \times 10^{4} / 50 \mu \mathrm{l}$ in PBS, mixed with $50 \mu \mathrm{l}$ of Matrigel (Becton Dickinson, CA, USA), and injected subcutaneously in 6-week-old female NOD/SCID mice (Harlan Italy, Milan, Italy). Each mouse received an adherent cell injection in the left flank and a spheroid-cell injection in the right flank. Mice were monitored every 3 days for the appearance of subcutaneous tumors. Tumor size was measured weekly with calipers. Tumor volume (V) was calculated as follows: $\mathrm{V}=\mathrm{W}^{2} \times \mathrm{L} \times 0.5$, where $\mathrm{W}$ and $\mathrm{L}$ were tumor width and length, respectively. After 45 days, mice were sacrificed, and the tumor tissue was collected and fixed in buffered formalin. Hematoxylin and eosin (H\&E) stain was performed to determine tumor histology. All procedures and experiments involving animals were approved and conducted according to the regulations of the Animal Ethic Committee of the Second University of Naples.

\section{In vitro treatment with cisplatin}

Cisplatin (cis-diammineplatinum (II) dischloride, DDP) (Sigma-Aldrich, St. Louis, MO, USA) was dissolved in sterile $0.9 \% \mathrm{NaCl}$ to achieve a stock concentration of $5 \mathrm{mM}$. Cells were plated $3-5 \times 10^{5}$ in $25 \mathrm{~cm}^{2}$ flasks, left to grow for 24 hours, and then treated. To establish cisplatin dosage for further experiments, cytotoxic curves were performed with Annexin V/PI staining kit on adherent cells at the concentrations of $2 \mu \mathrm{M}, 5 \mu \mathrm{M}, 20 \mu \mathrm{M}, 40 \mu \mathrm{M}$, $80 \mu \mathrm{M}$, and $100 \mu \mathrm{M}$ for 24 hours (Supplementary Figure 1). The cisplatin dose was chosen in order to produce at least $20 \%$ reduction in viability. Cells were then treated with cisplatin $80 \mu \mathrm{M}$ for 24 hours in the subsequent experiment.

\section{In vitro treatment with radiation}

Cells are irradiated at the Experimental Irradiation Core of the Comprehensive Cancer Center, University of Michigan. 250kV X-ray radiation (Philips RT250, Kimtron Medical) was delivered at a dose rate of approximately $2 \mathrm{~Gy} / \mathrm{min}$. Dosimetry was carried out with an electrometer system directly traceable to a National Institute of Standards and Technology calibration. Both cell lines considered were given $6 \mathrm{~Gy}$.

\section{IC50 calculation and MTT assay}

In order to calculate IC50, a dose-response curve was obtained by treating both cell lines with cisplatin, either in adherent or sphere culture conditions. Cells were plated at $1 \times 10^{4}$ per well in 96 -well plates before treatment with the following concentrations of cisplatin: $2 \mu \mathrm{M}, 5$ $\mu \mathrm{M}, 20 \mu \mathrm{M}, 40 \mu \mathrm{M}, 80 \mu \mathrm{M}, 120 \mu \mathrm{M}$, and $180 \mu \mathrm{M}$. After $24 \mathrm{~h}$ of treatment, MTT solution ( $1 \mathrm{mg} / \mathrm{mL}$ in PBS) was added to each well. The plates were then incubated at $37{ }^{\circ} \mathrm{C}$ for $4 \mathrm{~h}$, and reduced purple-blue MTT formazan crystals were solubilized by adding $200 \mu \mathrm{L}$ of DMSO to each well. The absorbance was measured at $595 \mathrm{~nm}$ using a microplate ELISA reader, with DMSO used as the blank. IC50 was calculated using Prism GraphPad Sofware (GraphPad Software, La Jolla, CA USA).

\section{Colony Forming Assay}

Orospheres and adherent cells received either $80 \mu \mathrm{M}$ cisplatin for 24 hours or $6 \mathrm{~Gy}$. Cells were then washed twice with PBS, adherent cell detached, and orospheres disaggregated using trypsin/EDTA for 5 minutes. Cells were then seeded at $250 / \mathrm{cm}^{2}$. Untreated cells for both adherent cultures and orospheres were used as control and to assess plating efficiency. Cultures were observed for 7-14 days (depending on growth rate differences between cell lines) to allow untreated cells to reach $>50$ 
cells/colony. Colonies were then fixed and stained with crystal violet in $20 \%$ methanol. Plating efficiency (PE) was calculated by dividing the number of colonies formed in the no treatment group by the number of cells seeded ( $\mathrm{PE}=\#$ of colonies formed/\# of cells seeded). Survival fraction (SF) was determined by colonies formed after treatment divided by the number of cells seeded multiplied by the plating efficiency ( $\mathrm{SF}=\#$ colonies formed/\# of cells seeded x PE). All experiments were done in triplicate.

\section{Shear flow assay}

Regular and E-selectin stably transfected Chinese Hamster Ovarian cells (CHO and E-sel-CHO cells were a gift from Dr Lloyd Stoolman, Pathology Department, University of Michigan), that grow as monolayers in culture, were maintained in MEM- $\alpha$ media $(20 \% \mathrm{FBS}$, $1 \mathrm{X}$ NEAA, $1 \mathrm{X}$ pen-strep). CHO cells were counted using a Beckman Coulter Counter and then incubated with the fluorescent marker CFSE (5-(and -6)-carboxyfluorescein diacetate succinimidyl ester) diluted with PBS $(25 \mu \mathrm{M})$ for 30 minutes. The cells were then centrifuged for 5 minutes at $1300 \mathrm{rpm}$, re-suspended at $1 \times 10^{6} \mathrm{cell} / \mathrm{ml}$ and incubated for 30 minutes in DMEM media $(10 \%$ FBS, 1X NEAA, 1X pen-strep). The tumor cells were perfused over the $\mathrm{CHO}$ monolayer at 1.4 dynes $/ \mathrm{cm}^{2}$ using a Harvard Apparatus. The shear force was calculated using the equation $y=6 Q \mu / b h 2$, where $y$ is the shear force in dynes $/ \mathrm{cm}^{2}, \mathrm{Q}$ is the flow rate in $\mathrm{mL} / \mathrm{sec}, \mu$ is the apparent viscosity (which is 0.01 poise for water at $32^{\circ} \mathrm{C}$ ), and $\mathrm{b}$ is the width and $\mathrm{h}$ is the height of the gasket. A gasket with dimensions of $0.005 \mathrm{~cm}$ in height and $0.25 \mathrm{~cm}$ wide was used. A computer software program, SIMPLE40, was employed to analyze the recorded video in conjunction with a standard CCD camera. Two-minute segments of the videos were analyzed at various time points and positions throughout the flow adhesion assay. An average was taken of the total number of cells that were either considered rolling or sticking to the monolayer, so that a value of cells per field was obtained and compared. 'Rolling' cells were considered to have velocities from 1.2-100 $\mu \mathrm{m} / \mathrm{s}$; 'sticking' cells had velocities of $0-1.2 \mu \mathrm{m} / \mathrm{s}$.

\section{Invasion Assay}

The invasion assays were performed using BD BioCoat Matrigel Invasion Chamber and BD control inserts (Becton-Dickinson, MA). The cells, as orospheres and sorted for SLe ${ }^{\mathrm{x}}$ expression by flow cytometry, were re-suspended in serum-free DMEM and then added onto inserts with uncoated filter (control inserts) or onto inserts with Matrigel coated filters (Invasion chambers) at the density of $5 \times 10^{4}$ cells/insert. DMEM containing $10 \%$ FBS was used as the chemoattractant. After incubation of 22 hours at $37^{\circ} \mathrm{C}, 5 \% \mathrm{CO}_{2}$, non-invading cells on the upper side of the membrane were removed with cotton swabs and the invading cells were fixed using methanol and stained with hematoxylin. Cells that invaded were counted at 200X magnification. Each assay was performed in triplicate. Invasion was calculated as percentage of cells that invaded the Matrigel insert compared to the number of cells that migrate in the control insert.

\section{Statistical analysis}

Statistical analyses were carried out by University of Michigan Center for Statistical Consultation and Research (CSCAR). An Independent Samples test was run using the SPSS program to analyze the significance of the differences found. P-values less than 0.05 were considered to be statistically significant. In all graphs, error bars represent the $95 \%$ confidence interval.

\section{ACKNOWLEDGMENTS}

This work was conducted as part of an established collaboration between University of Michigan Schools of Dentistry and Medicine and the Department of Experimental Medicine, Section of Biotechnology and Medical Histology and Embryology of the Second University of Naples, Italy. This work was supported by the following grants: European Grant PON01_02834 Prometheus to G.P. and University of Michigan U-M NCI/ NIDCR P50 CA 97248 (Head and Neck Cancer SPORE - Career Development Award to S.P.) and Research Scholar Grant RSG-13-103-01-CCE from the American Cancer Society (PI: Silvana Papagerakis, MD/ PhD) at the University of Michigan Ann Arbor. None of the funding sources had any role in the design, conduct, or interpretation of the above-mentioned experiments. The authors would like to thank the University of Michigan Flow Cytometry, Experimental Irradiation and DNA Cores, as well as the Center for Statistical Consultation and Research at the University of Michigan, and the Second University of Naples Animal Experimental Core for their expert help in acquiring these data.

\section{Conflict of interest}

The authors indicate no potential conflicts of interest.

\section{Author contributions}

S.P., P.P., G.P. and V.D.: conception and design, provision of study material, collection and/or assembly of data, data analysis and interpretation, manuscript writing; V.T., F.P., L.Z., R.M., L.M., M.M. F.P. and M.E.P.: experiment performing; collection and/or assembly of 
data; V.D. and G.P.: final approval of manuscript.

\section{REFERENCES}

1. Scully C and Bagan J. Oral squamous cell carcinoma overview. Oral oncology. 2009; 45(4-5):301-308.

2. Warnakulasuriya S. Global epidemiology of oral and oropharyngeal cancer. Oral oncology. 2009; 45(4-5):309316.

3. Zhang P, Zhang Y, Mao L, Zhang Z and Chen W. Side population in oral squamous cell carcinoma possesses tumor stem cell phenotypes. Cancer letters. 2009; 277(2):227-234.

4. Kelly C, Paleri V, Downs C and Shah R. Deterioration in quality of life and depressive symptoms during radiation therapy for head and neck cancer. Otolaryngology--head and neck surgery : official journal of American Academy of Otolaryngology-Head and Neck Surgery. 2007; 136(1):108111.

5. Rogers SN, Ahad SA and Murphy AP. A structured review and theme analysis of papers published on 'quality of life' in head and neck cancer: 2000-2005. Oral oncology. 2007; 43(9):843-868

6. Liebertz DJ, Lechner MG, Masood R, Sinha UK, Han J, Puri RK, Correa AJ and Epstein AL. Establishment and characterization of a novel head and neck squamous cell carcinoma cell line USC-HN1. Head \& neck oncology. $2010 ; 2: 5$.

7. McCullough MJ, Prasad G and Farah CS. Oral mucosal malignancy and potentially malignant lesions: an update on the epidemiology, risk factors, diagnosis and management. Australian dental journal. 2010; 55 Suppl 1:61-65.

8. Choi S and Myers JN. Molecular pathogenesis of oral squamous cell carcinoma: implications for therapy. Journal of dental research. 2008; 87(1):14-32.

9. Parkin DM, Bray F, Ferlay J and Pisani P. Global cancer statistics, 2002. CA: a cancer journal for clinicians. 2005; 55(2):74-108

10. Clarke MF, Dick JE, Dirks PB, Eaves CJ, Jamieson CH, Jones DL, Visvader J, Weissman IL and Wahl GM. Cancer stem cells--perspectives on current status and future directions: AACR Workshop on cancer stem cells. Cancer research. 2006; 66(19):9339-9344.

11. Ward RJ and Dirks PB. Cancer stem cells: at the headwaters of tumor development. Annual review of pathology. 2007; $2: 175-189$

12. Dewan MZ, Ahmed S, Iwasaki Y, Ohba K, Toi M and Yamamoto N. Stromal cell-derived factor-1 and CXCR4 receptor interaction in tumor growth and metastasis of breast cancer. Biomedicine \& pharmacotherapy = Biomedecine \& pharmacotherapie. 2006; 60(6):273-276.

13. Tirino V, Desiderio V, Paino F, De Rosa A, Papaccio F, La Noce M, Laino L, De Francesco F and Papaccio G. Cancer stem cells in solid tumors: an overview and new approaches for their isolation and characterization. FASEB journal : official publication of the Federation of American Societies for Experimental Biology. 2013; 27(1):13-24.

14. Desiderio V, Paino F, Nebbioso A, Altucci L, Pirozzi G, Papaccio F, La Noce M, De Rosa A, Papaccio G and Tirino V. Molecular Profiling of Human Primary ChondrosarcomaDerived Spheres Reveals Specific and Target Genes Involved in Multidrug Resistance and Metastasis. Journal of Carcinogenesis \& Mutagenesis. 2013; 5(1).

15. Tirino V, Desiderio V, Paino F, Papaccio G and De Rosa M. Methods for cancer stem cell detection and isolation. Methods in molecular biology. 2012; 879:513-529.

16. Rappa G, Mercapide J, Anzanello F, Prasmickaite L, Xi $\mathrm{Y}, \mathrm{Ju}$ J, Fodstad O and Lorico A. Growth of cancer cell lines under stem cell-like conditions has the potential to unveil therapeutic targets. Experimental cell research. 2008; 314(10):2110-2122.

17. Al-Hajj M, Wicha MS, Benito-Hernandez A, Morrison SJ and Clarke MF. Prospective identification of tumorigenic breast cancer cells. Proceedings of the National Academy of Sciences of the United States of America. 2003; 100(7):3983-3988.

18. Kim CF, Jackson EL, Woolfenden AE, Lawrence S, Babar I, Vogel S, Crowley D, Bronson RT and Jacks T. Identification of bronchioalveolar stem cells in normal lung and lung cancer. Cell. 2005; 121(6):823-835.

19. O'Brien CA, Pollett A, Gallinger S and Dick JE. A human colon cancer cell capable of initiating tumour growth in immunodeficient mice. Nature. 2007; 445(7123):106-110.

20. Collins AT, Berry PA, Hyde C, Stower MJ and Maitland NJ. Prospective identification of tumorigenic prostate cancer stem cells. Cancer research. 2005; 65(23):1094610951.

21. Szotek PP, Pieretti-Vanmarcke R, Masiakos PT, Dinulescu DM, Connolly D, Foster R, Dombkowski D, Preffer F, Maclaughlin DT and Donahoe PK. Ovarian cancer side population defines cells with stem cell-like characteristics and Mullerian Inhibiting Substance responsiveness. Proceedings of the National Academy of Sciences of the United States of America. 2006; 103(30):11154-11159.

22. Piccirillo SG, Reynolds BA, Zanetti N, Lamorte G, Binda E, Broggi G, Brem H, Olivi A, Dimeco F and Vescovi AL. Bone morphogenetic proteins inhibit the tumorigenic potential of human brain tumour-initiating cells. Nature. 2006; 444(7120):761-765.

23. Tirino V, Desiderio V, Paino F, De Rosa A, Papaccio F, Fazioli F, Pirozzi G and Papaccio G. Human primary bone sarcomas contain CD133+ cancer stem cells displaying high tumorigenicity in vivo. FASEB journal : official publication of the Federation of American Societies for Experimental Biology. 2011; 25(6):2022-2030.

24. Prince ME, Sivanandan R, Kaczorowski A, Wolf GT, Kaplan MJ, Dalerba P, Weissman IL, Clarke MF and Ailles LE. Identification of a subpopulation of cells with cancer stem cell properties in head and neck squamous 
cell carcinoma. Proceedings of the National Academy of Sciences of the United States of America. 2007; 104(3):973978.

25. Marques ETA, Jr. (2000). Fucosyltransferases In: Ernst B, Hart, G. W., Sinay, P, ed. Carbohydrate in Chemistry and Biology. (Weinheim: Wiley-VCH), pp. 197-211.

26. Clarke JL and Watkins W. Alpha1,3-L-fucosyltransferase expression in developing human myeloid cells. Antigenic, enzymatic, and mRNA analyses. The Journal of biological chemistry. 1996; 271(17):10317-10328.

27. Wiederschain GY, Koul O, Aucoin JM, Smith FI and McCluer RH. alpha1,3 Fucosyltransferase, alpha-Lfucosidase, alpha-D-galactosidase, beta-D-galactosidase, and $\operatorname{Le}(\mathrm{x})$ glycoconjugates in developing rat brain. Glycoconjugate journal. 1998; 15(4):379-388.

28. Blander JM, Visintin I, Janeway CA, Jr. and Medzhitov R. Alpha(1,3)-fucosyltransferase VII and alpha(2,3)sialyltransferase IV are up-regulated in activated CD4 T cells and maintained after their differentiation into Th1 and migration into inflammatory sites. Journal of immunology. 1999; 163(7):3746-3752.

29. Lowe JB. Selectin ligands, leukocyte trafficking, and fucosyltransferase genes. Kidney international. 1997; 51(5):1418-1426.

30. Chandrasekaran EV, Xue J, Piskorz C, Locke RD, Toth K, Slocum HK and Matta KL. Potential tumor markers for human gastric cancer: an elevation of glycan:sulfotransferases and a concomitant loss of alpha1,2fucosyltransferase activities. Journal of cancer research and clinical oncology. 2007; 133(9):599-611.

31. Etzioni A, Frydman M, Pollack S, Avidor I, Phillips ML, Paulson JC and Gershoni-Baruch R. Brief report: recurrent severe infections caused by a novel leukocyte adhesion deficiency. The New England journal of medicine. 1992; 327(25):1789-1792.

32. Fukuda T, Hashimoto H, Okayasu N, Kameyama A, Onogi H, Nakagawasai O, Nakazawa T, Kurosawa T, Hao Y, Isaji T, Tadano T, Narimatsu H, Taniguchi $\mathrm{N}$ and $\mathrm{Gu}$ J. Alpha1,6-fucosyltransferase-deficient mice exhibit multiple behavioral abnormalities associated with a schizophrenialike phenotype: importance of the balance between the dopamine and serotonin systems. The Journal of biological chemistry. 2011; 286(21):18434-18443.

33. McGovern DP, Jones MR, Taylor KD, Marciante $\mathrm{K}$, Yan X, Dubinsky M, Ippoliti A, Vasiliauskas E, Berel D, Derkowski C, Dutridge D, Fleshner P, Shih DQ, Melmed G, Mengesha E, King L, et al. Fucosyltransferase 2 (FUT2) non-secretor status is associated with Crohn's disease. Human molecular genetics. 2010; 19(17):3468-3476.

34. de Vries T, Knegtel RM, Holmes EH and Macher BA. Fucosyltransferases: structure/function studies. Glycobiology. 2001; 11(10):119R-128R.

35. Clay MR, Tabor M, Owen JH, Carey TE, Bradford CR, Wolf GT, Wicha MS and Prince ME. Single-marker identification of head and neck squamous cell carcinoma cancer stem cells with aldehyde dehydrogenase. Head \& neck. 2010; 32(9):1195-1201.

36. Medema JP. Cancer stem cells: the challenges ahead. Nature cell biology. 2013; 15(4):338-344.

37. Owens GC, Orr EA, DeMasters BK, Muschel RJ, Berens $\mathrm{ME}$ and Kruse CA. Overexpression of a transmembrane isoform of neural cell adhesion molecule alters the invasiveness of rat CNS-1 glioma. Cancer research. 1998; 58(9):2020-2028.

38. Tsuchiya A, Kamimura H, Tamura Y, Takamura M, Yamagiwa S, Suda T, Nomoto $M$ and Aoyagi $Y$. Hepatocellular carcinoma with progenitor cell features distinguishable by the hepatic stem/progenitor cell marker NCAM. Cancer letters. 2011; 309(1):95-103.

39. Yang AH, Chen JY, Lee $\mathrm{CH}$ and Chen JY. Expression of NCAM and OCIAD1 in well-differentiated thyroid carcinoma: correlation with the risk of distant metastasis. Journal of clinical pathology. 2012; 65(3):206-212.

40. Romanini J, Mielcke TR, Leal PC, Figueiredo CP, Calixto JB, Morrone FB, Batista EL, Jr. and Campos MM. The role of CXCR2 chemokine receptors in the oral squamous cell carcinoma. Investigational new drugs. 2012; 30(4):13711378.

41. Justilien V, Regala RP, Tseng IC, Walsh MP, Batra J, Radisky ES, Murray NR and Fields AP. Matrix metalloproteinase-10 is required for lung cancer stem cell maintenance, tumor initiation and metastatic potential. PloS one. 2012; 7(4):e35040.

42. Nolan ME, Aranda V, Lee S, Lakshmi B, Basu S, Allred DC and Muthuswamy SK. The polarity protein Par6 induces cell proliferation and is overexpressed in breast cancer. Cancer research. 2008; 68(20):8201-8209.

43. Giotakis I, Chrysovergis A, Georgolios A, Giotakis E and Manolopoulos L. Adhesion molecules in cancer of the head and neck: role of dysadherin. Journal of BUON : official journal of the Balkan Union of Oncology. 2011; 16(4):609612.

44. Lim YC, Oh SY, Cha YY, Kim SH, Jin X and Kim H. Cancer stem cell traits in squamospheres derived from primary head and neck squamous cell carcinomas. Oral oncology. 2011; 47(2):83-91.

45. Krishnamurthy $\mathrm{S}$ and Nor JE. Orosphere assay: a method for propagation of head and neck cancer stem cells. Head \& neck. 2013; 35(7):1015-1021.

46. Wang X, Chen J, Li QK, Peskoe SB, Zhang B, Choi C, Platz EA and Zhang H. Overexpression of alpha $(1,6)$ fucosyltransferase associated with aggressive prostate cancer. Glycobiology. 2014.

47. Li J, Guillebon AD, Hsu JW, Barthel SR, Dimitroff CJ, Lee YF and King MR. Human fucosyltransferase 6 enables prostate cancer metastasis to bone. British journal of cancer. 2013; 109(12):3014-3022.

48. Barthel SR, Gavino JD, Wiese GK, Jaynes JM, Siddiqui 
J and Dimitroff CJ. Analysis of glycosyltransferase expression in metastatic prostate cancer cells capable of rolling activity on microvascular endothelial (E)-selectin. Glycobiology. 2008; 18(10):806-817.

49. Okeley NM, Alley SC, Anderson ME, Boursalian TE, Burke PJ, Emmerton KM, Jeffrey SC, Klussman K, Law CL, Sussman D, Toki BE, Westendorf L, Zeng W, Zhang $\mathrm{X}$, Benjamin DR and Senter PD. Development of orally active inhibitors of protein and cellular fucosylation. Proceedings of the National Academy of Sciences of the United States of America. 2013; 110(14):5404-5409.

50. Yin X, Rana K, Ponmudi V and King MR. Knockdown of fucosyltransferase III disrupts the adhesion of circulating cancer cells to E-selectin without affecting hematopoietic cell adhesion. Carbohydrate research. 2010; 345(16):23342342.

51. Prince ME and Ailles LE. Cancer stem cells in head and neck squamous cell cancer. Journal of clinical oncology : official journal of the American Society of Clinical Oncology. 2008; 26(17):2871-2875.

52. Mack B and Gires O. CD44s and CD44v6 expression in head and neck epithelia. PloS one. 2008; 3(10):e3360.

53. Davis SJ, Divi V, Owen JH, Bradford CR, Carey TE, Papagerakis S and Prince ME. Metastatic potential of cancer stem cells in head and neck squamous cell carcinoma. Archives of otolaryngology--head \& neck surgery. 2010; 136(12):1260-1266.

54. Wang SJ, Wong G, de Heer AM, Xia W and Bourguignon LY. CD44 variant isoforms in head and neck squamous cell carcinoma progression. The Laryngoscope. 2009; 119(8):1518-1530.

55. Cojoc M, Mabert K, Muders MH and Dubrovska A. A role for cancer stem cells in therapy resistance: Cellular and molecular mechanisms. Seminars in cancer biology. 2014.

56. Springer TA and Lasky LA. Cell adhesion. Sticky sugars for selectins. Nature. 1991; 349(6306):196-197.

57. Czerwinski MJ, Desiderio V, Shkeir O, Papagerakis P, Lapadatescu MC, Owen JH, Athanassiou-Papaefthymiou M, Zheng L, Papaccio G, Prince ME and Papagerakis S. In vitro evaluation of sialyl Lewis $\mathrm{X}$ relationship with head and neck cancer stem cells. Otolaryngology--head and neck surgery : official journal of American Academy of Otolaryngology-Head and Neck Surgery. 2013; 149(1):97104.

58. Nakagoe T, Fukushima K, Nanashima A, Sawai T, Tsuji T, Jibiki M, Yamaguchi H, Yasutake T, Ayabe H, Matuo T, Tagawa Y and Arisawa K. Expression of Lewis(a), sialyl Lewis(a), Lewis(x) and sialyl Lewis(x) antigens as prognostic factors in patients with colorectal cancer. Canadian journal of gastroenterology $=$ Journal canadien de gastroenterologie. 2000; 14(9):753-760.

59. Portela SV, Martin CV, Romay LM, Cuevas E, Martin EG and Briera AF. sLea and sLex expression in colorectal cancer: implications for tumourigenesis and disease prognosis. Histology and histopathology. 2011; 26(10):1305-1316.

60. St Hill CA, Baharo-Hassan D and Farooqui M. C2-O-sLeX glycoproteins are E-selectin ligands that regulate invasion of human colon and hepatic carcinoma cells. PloS one. 2011; 6(1):e16281.

61. Yu CJ, Shih JY, Lee YC, Shun CT, Yuan A and Yang PC. Sialyl Lewis antigens: association with MUC5AC protein and correlation with post-operative recurrence of non-small cell lung cancer. Lung Cancer. 2005; 47(1):59-67.

62. Carvalho AS, Harduin-Lepers A, Magalhaes A, Machado E, Mendes N, Costa LT, Matthiesen R, Almeida R, Costa $\mathrm{J}$ and Reis CA. Differential expression of alpha-2,3sialyltransferases and alpha-1,3/4-fucosyltransferases regulates the levels of sialyl Lewis a and sialyl Lewis $\mathrm{x}$ in gastrointestinal carcinoma cells. The international journal of biochemistry \& cell biology. 2010; 42(1):80-89.

63. Higai K, Miyazaki N, Azuma Y and Matsumoto K. Interleukin-1beta induces sialyl Lewis $\mathrm{X}$ on hepatocellular carcinoma HuH-7 cells via enhanced expression of ST3Gal IV and FUT VI gene. FEBS letters. 2006; 580(26):60696075.

64. Padro M, Cobler L, Garrido M and de Bolos C. Downregulation of FUT3 and FUT5 by shRNA alters Lewis antigens expression and reduces the adhesion capacities of gastric cancer cells. Biochimica et biophysica acta. 2011; 1810(12):1141-1149.

65. Trinchera M, Malagolini N, Chiricolo M, Santini D, Minni F, Caretti A and Dall'olio F. The biosynthesis of the selectin-ligand sialyl Lewis $\mathrm{x}$ in colorectal cancer tissues is regulated by fucosyltransferase VI and can be inhibited by an RNA interference-based approach. The international journal of biochemistry \& cell biology. 2011; 43(1):130139.

66. Julien S, Ivetic A, Grigoriadis A, QiZe D, Burford B, Sproviero D, Picco G, Gillett C, Papp SL, Schaffer L, Tutt A, Taylor-Papadimitriou J, Pinder SE and Burchell JM. Selectin ligand sialyl-Lewis $\mathrm{x}$ antigen drives metastasis of hormone-dependent breast cancers. Cancer research. 2011; 71(24):7683-7693.

67. Rillahan CD, Antonopoulos A, Lefort CT, Sonon R, Azadi P, Ley K, Dell A, Haslam SM and Paulson JC. Global metabolic inhibitors of sialyl- and fucosyltransferases remodel the glycome. Nature chemical biology. 2012; 8(7):661-668.

68. Cheng L, Luo S, Jin C, Ma H, Zhou H and Jia L. FUT family mediates the multidrug resistance of human hepatocellular carcinoma via the PI3K/Akt signaling pathway. Cell death \& disease. 2013; 4:e923.

69. Carey TE. (1999). Head and neck cancers. In: Masters J and Pallson B, eds. Human Cell Culture Kluver Accademic Publisher).

70. Owen JH, Hauff SJ, Tang AL, Graham MP, Czerwinski MJ, Kaddoura M, Papagerakis S, Bradford CR, Carey TE 
and Prince ME. UM-SCC-103: A Unique Tongue Cancer Cell Line That Recapitulates the Tumorigenic Stem Cell Population of the Primary Tumor. The Annals of otology, rhinology, and laryngology. 2014. 